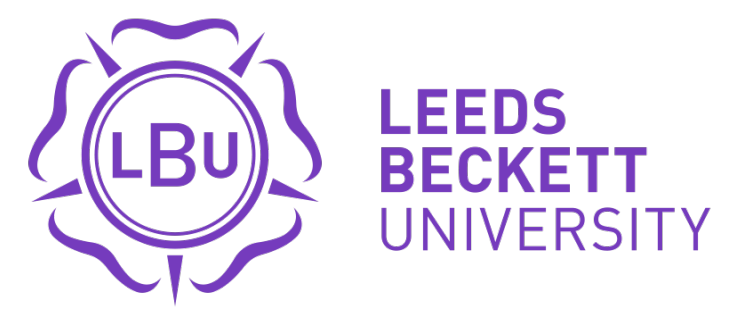

Citation:

Martinez, N and Martos-Garcia, D and Usabiaga, O and Martinez, N and Lozano, L (2019) Frictions, cracks and micro-resistances: physical activity and sport as strategies to dignify imprisoned women. Qualitative Research in Sport, Exercise and Health, 11 (2). pp. 217-230. ISSN 2159-676X DOI: https://doi.org/10.1080/2159676X.2018.1493526

Link to Leeds Beckett Repository record:

https://eprints.leedsbeckett.ac.uk/id/eprint/5318/

Document Version:

Article (Accepted Version)

This is an Accepted Manuscript of an article published by Taylor \& Francis in Qualitative Research in Sport, Exercise and Health on 02 Aug 2018, available online: http://www.tandfonline.com/10.1080/2159676X.2018.1493526

The aim of the Leeds Beckett Repository is to provide open access to our research, as required by funder policies and permitted by publishers and copyright law.

The Leeds Beckett repository holds a wide range of publications, each of which has been checked for copyright and the relevant embargo period has been applied by the Research Services team.

We operate on a standard take-down policy. If you are the author or publisher of an output and you would like it removed from the repository, please contact us and we will investigate on a case-by-case basis.

Each thesis in the repository has been cleared where necessary by the author for third party copyright. If you would like a thesis to be removed from the repository or believe there is an issue with copyright, please contact us on openaccess@leedsbeckett.ac.uk and we will investigate on a case-by-case basis. 


\section{Frictions, cracks and micro-resistances: physical activity and sport as strategies to dignify imprisoned women}

\section{Martinez-Merino Nagore ${ }^{\mathrm{a} *}$, Martos-Garcia Daniel ${ }^{\mathrm{b}}$, Lozano-Sufrategui \\ Lorena $^{\mathrm{c}}$, Martín-González ${ }^{\mathrm{a}}$, Nerian and Usabiaga Oidui ${ }^{\mathrm{a}}$}

${ }^{a}$ Physical and Sport Education Department, University of the Basque Country, Vitoria-

Gasteiz, Spain; ${ }^{b}$ Department of Teaching of Music Plastic and Corporal Expression,

University of Valencia, València, Spain; ' School of Sport Department, Leeds Beckett

University, Leeds, United Kingdom.

Provide full correspondence details here nagore.martinez@ehu.eus for the *corresponding author

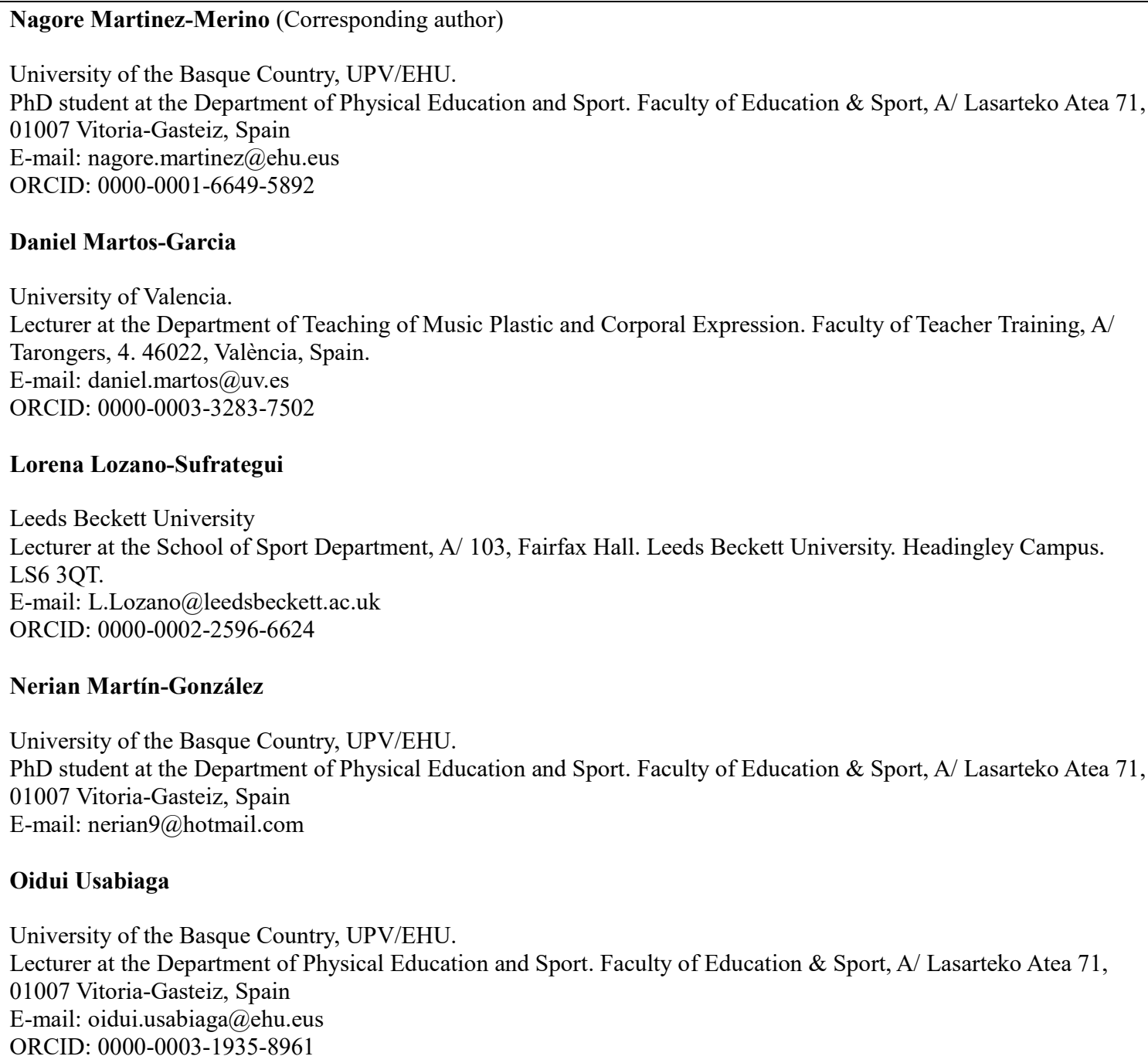

This work was supported by the Basque Government under Grant [PRE_2014_1_297] 


\title{
Frictions, cracks and micro-resistances: physical activity and sport as strategies to dignify imprisoned women
}

\begin{abstract}
In capitalist societies, where discipline and control are dominant concepts, prisons are a warning tool about the consequences of non-conformity. In this context, prisoners are exposed to a type of power that is used as a corrective technique to transform them into docile and useful citizens. However, such power is not static and inmates can create various strategies of resistance. The aim of this research is to understand how physical activity and sport are used by incarcerated women to confront social control in Spanish prisons. Based on 16 interviews with former female inmates, we found that engaging in physical activity and sports helped participants to cope with their sentences. These activities were also used as tools to confront and negotiate the patriarchal punitive power often found in prisons, meaning that participants were not put down by it. Participants' abilities to minimally destabilize the prison's order also empowered them to regain some autonomy and identity. Through participating in physical activity and sports, incarcerated women created spaces of freedom and frictions within a limiting prohibitive prison environment.
\end{abstract}

Keywords: Prison; sport; female; resistance; social control.

\section{Introduction}

Agency and resistance can empower inmates to challenge the punitive power experienced in prisons (e.g. Bosworth 1999, Ugelvik 2014). Some ways for prisoners to challenge and resist penitentiary social control may include the participation in sport and physical activity (Martos-Garcia et al. 2009a, Norman 2015). However, research in this area is yet to explore whether, and if so how, incarcerated women engage sport and physical activity as acts of resistance or micro-resistance. Underpinned by the notion of friction (Digeser 1992, p.995), and applying this concept within a penitentiary context (Rubin 2015), this research aims to shed light on how sport and physical activity are used by incarcerated 
women to confront social control and negotiate power relations in Spanish prisons. We interviewed 16 women who had previously been incarcerated, and we asked them about their experiences of physical activity and sport in prison. The analysis of these interviews suggests that women can experience physical activity and sports as an opportunity to confront the institution, regain some autonomy and create spaces of freedom while being imprisoned.

Prisoners are seen as individuals who have breached the social pact, and thus they constitute a threat to society. These 'non-productive' individuals are locked up in prisons and subjected to corrective techniques (Foucault 1995). A common view is that prisoners are in debt to the society where they were expelled from, and thus deserve to be punished. With these thoughts in mind, Davis (2016a, p. 35) may not exaggerate when noting that "prisons have become a black hole into which the debris of contemporary capitalism is deposited”.

The advent of modern capitalist societies reinforced new forms of social relationships, economic production and private property. These capitalist developments gave rise to antisocial behaviours like looting, theft and delinquency, which are not tolerated by powerful social forces (Matthews 2009). Owing to this, penal codes were established to protect societies from punishable behaviours. This resulted in the rise of numerous new offences, with respect to regularity, law and order (Foucault 1996). In this context, the art of punishment is a symbolic game of power and control, in which punishment is used to make offence less attractive (Foucault 1995). Offence is perceived as a transgression of a "just" and "egalitarian" society, and it is often sanctioned by usurping the only element that all citizens have in common: their individual freedom (Matthews 2009). Surprisingly, these efforts have not resulted in a reduction of crime rates. This may be because incarceration does not seek to suppress criminality, but to 
warn citizens about the consequences of non-conformity, reminding them that their behaviours are controlled by strong social forces (Foucault 1995, Matthews 2009). Consequently, prisons have become a storehouse of 'undesirables' (Wacquant 2009).

Almeda (2005) added a gender perspective to Foucault's historical and philosophical analysis of the metamorphosis of penalty. Specifically, Almeda highlighted the evolution of the discrimination suffered by women in Spanish prisons, from the origins of the deprivation of freedom until today. According to her, imprisonment not only serves to "Discipline \& Punish", but it also seeks to 'correct' incarcerated women through sexist treatment, in order to domesticate them. Spanish punishment reinforces the patriarchal structure of society by fostering and building certain behaviours, stereotypes and gender roles (Almeda 2005, De Miguel-Calvo 2016). Importantly, the consequences of confinement, including stigmatisation, are often more harmful for women than for men. This is because women prisoners are seen as transgressors of not only social laws and sanctions, but also of gender norms. As a result, women prisoners must be 'corrected' (De Miguel-Calvo 2016) through traditional forms of female punishment: a singular combination of strict discipline, direct control and blind obedience (Ballesteros-Pena, 2017).

According to Foucault (1995), during the 18th century and the early 19th century, there was a shift in the paradigm of prisons which resulted in an enhanced integration and cultural change. Since then, prisoners have been considered human beings with human rights, despite the fact that they are imprisoned. Following this, similar to health, culture, work and education, access to sport is also considered a human right (Meek 2014). Thus, opportunities to participate in physical activity and sport have increased in Spain (MartosGarcia, 2009b), but women only represent a small amount of all the prison population 
$(7.42 \%)^{1}$ in Spain. Further, only three Spanish prisons out of 69 are women-only, meaning that women are often incarcerated in small units within male-dominated prisons (Almeda 2005). In Spanish prisons, women have limited opportunities to participate in cultural activities or work (Almeda 2005, De Miguel-Calvo 2016). When these are available, they often include traditional female activities such as cooking, sewing, cosmetics, hairdressing, and so on. The range of sport and physical activity programmes on offer vary between prisons. As opposed to mixed gender prisons, female-only prisons are more likely to provide structured sport and physical activity programmes. When sport and physical activity are offered in mixed prisons, these are frequently tailored for men, which limits women's opportunities to participate (Martos-Garcia et al. 2009a). Furthermore, when physical activity programmes are offered for women, these often include activities that are traditionally seen as feminine, such as volleyball, badminton, Zumba and aerobics (Martinez-Merino et al. 2017).

With regards to the daily schedules, prisoners have limited opportunities to remain in their cells. Prisoners are often forced to leave their cells and spend time in the common areas, in their work shifts, or in the scheduled activities, unless they have been given a special permission or are in solitary confinement. There is often a small yard in the prisoners' unit where they can participate in physical activity or sports. Most prisons also have a sports hall, although in many occasions these need renovating. Prisoners who may want to use the sports hall have to be registered to confirm their eligibility to use the facility. Such eligibility is based on a number of criteria, including their current situation and behaviour (Martos-Garcia et al. 2009a).

\footnotetext{
${ }^{1}$ Stadistics of the first week of January, 2018: http://www.institucionpenitenciaria.es/web/portal/documentos/estadisticas.html?r=s\&asem=2018\&msem $=1 \& \mathrm{dsem}=8 \& \mathrm{ts}=\mathrm{GENE}$
} 


\section{Resistance, agency and frictions}

The notion of friction proposed by Rubin (2015) is the key theoretical concept underpinning this study, which is also influenced by Foucault's and Goffman's theories on power and prison. According to Foucault (1982, 1990), discipline and control are key concepts within industrial and capitalist societies, and these power relationships are deeprooted within the social fabric. For Foucault, power - the action of one person over another - always brings resistance, which can be as creative, mobile and productive as the power that generates it. Hence, rebels may display a wide array of reactions, responses and inventions to confront a source of power. Rebellion is aimed at minimising the effect of power.

Punitive power is exerted within prisons as a corrective technique to transform women into docile and useful citizens (Foucault 1995). Restrepo and Frances (2016) identified a patriarchal punitive power, when they referred to the close relationship they found between some characteristics of punitive power and patriarchal oppression. However, similar to life outside prison, the type of power that is displayed in prisons is not static. When dominated, individuals may display a range of behaviours, from rebellion to absolute submission. Such constant dialectic between power and confrontation is a likely reality to be found in prisons (Crewe 2007), and prisoners can create various strategies of resistance (Bosworth and Carrabine 2001, Ugelvik 2014). For Bosworth (1999), exploring women's ability to negotiate power (i.e. agency exploration) can help us understand how women evaluate and negotiate power relationships under maximum domination. In this regard, prisoners use strategies of resistance to create free spaces that enable them to escape from the tedious prison routine. For Ugelvik (2014), escaping frees inmates from their prisoner status. According to Bosworth and Carrabine (2001), resistance can be a prisoner's way of demonstrating that they have not been fully 
deprived of their personal autonomy. By resisting, prisoners show that they are active, capable and skilled individuals, able to transform power relationships.

Foucault's (1982) framework of war or play can help contextualise the strategies used by prisoners to confront power. In a prison environment, confrontations are wars between two groups, where strategies are practical mechanisms to deal with power relationships. The relevant literature shows that prisoners use various tactics in search of a more pleasurable imprisonment experience, both in terms of short sentences (Schmid and Jones 1993) and long sentences (Hulley et al. 2015). The concepts 'resistance' or 'strategy' have been related to Goffman's (1961) notion of 'secondary adjustments'. Prisoners use these adjustments to distance themselves from the role the 'total institution' has given them. They do this by using techniques or any other available means to achieve unofficial goals. By doing so, prisoners' lives are modified and improved.

For instance, Rubin (2015) distinguished between the notions of secondary adjustment or resistance and friction. For her, a behaviour is seen as 'resistance' when it is intentional. Therefore, it is essential to know the prisoners' intention when behaving in a way that may be seen as an act of resistance. In this sense, resistance implies a conscious action that holds a political interest and/or a destabilising intent against powerful prison authorities. When referring to 'friction', this term relates to the reactive behaviours that result when people try to find themselves in controlled spaces (Rubin 2015). In short, frictions are daily actions of micro-resistance, where prisoners actively create their own space to regain some control over their own lives. It should not be overlooked that when entering a total institution such as a prison, people undergo a mutilation of their personality, by which they lose part of their identity and any notion of control over their lives, as they are separated from their natural, social environment (Goffman 1961). Therefore, according to Rubin (2015), frictions can be understood as natural or automatic 
actions, motivated by human needs and occurring in an extremely controlled environment.

\section{Sport and physical activity as frictions?}

Sport and physical activity can be used as secondary adjustments, a form of escapism that prisoners may experience as liberating (Goffman 1961). Several authors have confirmed that participating in physical activity and sport can have an evasive effect on imprisoned women (Gallant et al. 2015, Martos-Garcia et al. 2009a, Tibbetts 2015). These studies have emphasised that physical activity and sport provide women with a sense of momentary freedom through which they can overlook their confinement, thus positively impacting on their quality of life (Martinez-Merino et al. 2017). Although physical activity and sport can become tools for social control (Martos-Garcia et al. 2009b), Norman (2015) concluded that they can act as an opposing force in prisons, by confronting the social control and constant oppression that prisoners are subjected to. With reference to this, De Graaf (2013) agreed that the physical body is a space of control and resistance for prisoners, with the practice of movement becoming a tool to reappropriate the prisoners' own body control.

The aim of this study is to explore how women use sport and physical activity as micro-resistance or friction weapons, and to understand the meaning of these behaviours. To do so, this study seeks to answer the following research questions: (i) Can sport and physical activity become tools to confront social control in prison?; and (ii) How can prisoners face the patriarchal punitive power through sport and physical activity?

\section{Method}

Research is dependent on the phenomenon it studies, so choices about methods have to consider the particularities of the research context. For these reasons, the research 
standards and requirements for studies undertaken within prisons are different from those studies that include other human groups (Schlosser 2008). Due to their confinement, prisoners are highly vulnerable individuals. For example, such vulnerability was evident when our participant Izar questioned some aspects of our research:

'Why are you studying the prison? Prison is pain, it's suffering... it hurts to talk about all this, you know? Why would you want to study this pain?'

This questioning was also reported by Martos-Garcia and Devís-Devís (2017), and suggests that delving into the sub-cultures of stigmatised people entails not only issues related to methods, but also to the epistemology underpinning the study. Understanding the complexity of these issues can be an intense and challenging experience (Bosworth 1999, Norman 2018). Thus, it is important that researchers in this field are prepared to cope with unpredictable difficulties and ethical dilemmas. This study is unique in many ways. First, it explores the understudied phenomenon of women's lives within androcentric institutions (De Miguel-Calvo 2016). Second, it combines the notions of stigma and vulnerability (i.e. the stigma of being a prisoner and the vulnerability of being a woman in prison). Third, as opposed to the male-dominated samples traditionally used in the field of sport and physical activity research in prison (Meek and Lewis 2014) or at liberty (Hargreaves and Anderson 2014), our unique study includes a female-only sample to shed light on these issues from a gendered perspective.

Using a qualitative methodology, we seek to explore the following: (i) the sport and physical activity experiences of imprisoned women; and (ii) the meaning and symbolic representations women make of those experiences. By doing this, we aim to understand whether sport and physical activity are frictions within this context. To achieve this, we chose a semi-structured, in-depth interview approach to explore women's accounts. 


\section{The participants}

The inclusion criteria for this study were: 1) to be a woman; 2) to have spent at least one year in prison; and 3) to have participated in any sport and/or physical activity when they were imprisoned. Participants were recruited through social associations that worked with women during their stages of criminal justice involvement. We contacted six associations within the geographical area where most of the research team is based. Four associations did not provide any contacts, perhaps meaning that none of the few women they worked with had participated in sport or physical activity during their time in prison. It may also mean that some women may not have received the information about the research, or that perhaps they were not interested in taking part. Two associations facilitated a list with the names of women who met the inclusion criteria. The managers of each association acted as gatekeepers and contacted potential participants, providing them with an overview of our research. Each manager then facilitated the contact details of each woman who voluntarily agreed to participate in our study. Following this, snowball sampling was used (Noy 2008), to recruit the desired number of participants. Data collection took place during 2014-2016 with 16 participants, who were not imprisoned at the time of data collection.

All participants had been previously incarcerated in Spanish prisons. Three participants completed their sentence in the same prison, and 13 were incarcerated in more than one prison (sometimes up to 8 different prisons). Participants' age at the time of the interview ranged between 21 to 63 years old. The most frequent crime was against public health (related to drug dealing) $(\mathrm{n}=10)$, and the sentences varied between three to 18 years. Two participants had criminal records for theft or shoplifting, but for most women this was their first (and only) experience of imprisonment. Out of the 16 participants, 10 had completed their sentences, and six were still in third grade 
imprisonment. This grade referred to a situation where they are 'free' during the day but they have to return to sleep in a centre controlled by the Spanish prison administration. Four participants had a history of drug abuse, and most had participated in some form of physical activity and/or sport before entering prison. One participant had participated in professional sport, but most of them had done it as a leisure activity, during school-age.

\section{The interview ethics and procedure}

During the first point of contact with participants, we explained to them the aims of the study and provided an opportunity for participants to ask any questions about it. We highlighted that it was important for us to listen to their stories first-hand, but also that they did not have to answer any questions they did not feel comfortable with. Participants who agreed to voluntarily participate in the study provided a signed consent form before any data collection took place, following the ethical guidelines at the University of the Basque Country. Interviews were tape recorded and included four key sections: (a) Opening questions about the participant's life before being arrested; (b) Her experiences in prison; (c) Experiences of physical activity and/or sport in prison; (d) Life after confinement. All interviews were transcribed verbatim.

When developing relationships with people who have been deprived of liberty, it is important to show a respectful attitude towards them as this helps build trust and rapport (Davis 2016b). Therefore, the interviewer displayed an attitude of care and respect towards participants, which facilitated a fluent and comfortable conversation. Under no circumstances did the interviewer mistrust the accounts provided by any of the interviewees. The use of open-ended questions meant that participants could choose what questions to answer and how to answer them. At the beginning and throughout each interview, the interviewer reminded the participants that they did not have to answer any 
questions if they did not want to. To conclude the interview, we asked participants how they felt during the interview and we provided an opportunity for them to ask any questions or share further comments. The role of the interviewer was to guide the conversation, providing opportunities for each participant to share their stories (Kvale 2007). After the interview had been transcribed, we shared the transcripts with participants in case they wanted to confirm the accuracy of the transcript, add something else, or resolve any uncertainties. Following Schlosser's (2008) recommendation, participants were invited to choose a pseudonym to ensure anonymity.

\section{The analysis}

Women's stories were broadly analysed inductively (Taylor et al. 2016), although the framing of the research questions and analysis was guided by our theoretical lens and background. We familiarized ourselves with the interview transcripts by reading and rereading them, and finding some preliminary themes. After this, we found key codes and with these, we formed categories, which were linked to current literature. One of the recurring themes emerging from the data was that of 'friction', which was associated with concepts such as agency, control, time, imagination, confrontation and survival. Given the gap in the scientific literature about the micro-resistances women prisoners can experience when participating in sport and physical activity, and its value within the tussle of prisoners' power relationships, the current literature on the overall themes was consulted to progress an in-depth analysis.

\section{Limitations of the study}

Although this study makes an important contribution to knowledge; it is not free from limitations. As Norman (2018) reminds us, it is difficult to investigate in, and about, total institutions like prisons. Furthermore, it seems that the prison walls are still high and hard 
to go through for suspicious outsiders. For this reason, we opted to interview women outside the jail context. Searching and looking for people who had been incarcerated was not an easy task, and doing it through social associations did have some limitations. Our sample of incarcerated women is also limited to those women who were in contact with the social association we contacted. Furthermore, women generally represent only a small part of the penitentiary population, and most women have low levels of physical activity in prisons (Lewis and Meek 2012.). Thus, finding women who had been physically active in prison and also willing to be interviewed proved to be challenging.

\section{Results and Discussion}

\section{Rebellion against control: they can't deny me this}

For many years, prisoners have disturbed and obstructed penitential order, despite being aware of the negative consequences these behaviours can entail. This was evident in the accounts provided by some participants:

Monica: All of that was because I came up against control and I was against the authority which was imposed on me in there ... which, well, we have spoken about it many times, that the normal thing, in a person, OK mentally, more or less as I said, is to rebel. Because being treated like treat us isn't natural. I don't know, not as a person, I'm not going to say as an animal, but not as a human being. Yes, control, too much control, too much control and too little empathy. [...] So, we deal with that with small acts of rebellion. It's related to taking substances and eluding reality.

Casandra: Amanda, she sewed up her mouth. The cuts, they were a bit much...

Monica: Look, it is clear that, as the measures are so desperate, a lot of them... they take their own life. That is, to cope. [...] So, if there was an escape valve, there, in that place [solitary confinement], there would not be so many hangings ... maybe ... Not that there were many but, let's see, since I, since ... I was there, there were a few ... eh? There were a few ... 
Women prisoners perceived this as a form of domination, and in this context they considered it natural to rebel against such control. As a result, they created diverse strategies to disobey the institution. For example, they got involved in minor confrontations, such as stealing syringes from the nurses, organising sabotage, sit-downs, and by even getting involved in violent acts against staff. These behaviours have provided them with 'small victories' against the prison as an institution. Even if they only lasted a few minutes, women prisoners achieved a destabilisation of order through the above actions. According to these women, being involved in these acts of rebellion gave them 'a lot of life'. As Ugelvik (2014, p. 6) noted, prisoners 'do freedom' and create spaces of freedom by confronting against power.

Likewise, the interview excerpts revealed the existence of recurring self-harm in prison. Self-harm has been interpreted as a way of regaining control over one's body through pain (De Graaf 2013). Taking this further, Matthews (2009) described suicide as an extreme form of resistance and confrontation within the institution. Unfortunately, suicide rates in women prisoners in Spain are high, with $13.3 \%$ of all female prisoners attempting it, according to the SPACE report, published by the European Council (Aebi et al. 2017).

As the interviewees suggested, suicidal thoughts are often aggravated by the isolation regime. The few 'escape valves' mentioned by Monica are often in the form of sport and physical activities (Gallant et al. 2015, Goffman 1961, Martinez-Merino et al. 2017, Martos-Garcia et al. 2009a, Tibbetts 2015). These practices make it possible for some women to move forward and face their sentences. This is what Ana said:

The judge decided that my daughter could not be with me anymore, so last year was very traumatic for me, and that's when I exercised the most. That was the only way for me to deal with my sadness, my anger and my restlessness... being unable to live with her, the separation ... exercise was the only way I had to survive. (Ana) 
In her attempt to have control over her life, Ana regained the desire to live (Rubin, 2015). In her words, exercising helped her to accept estrangement from her daughter, without relapsing into drug-taking, and also preventing a chronic from of depression. In this respect, and in accordance with Norman (2015), sport and physical activity crystallised into a symbolic instrument of survival.

By virtue of its nature, the prison setting has almost total control over the inmates therein, a control that is a constant succession of punishments and rewards (Foucault 1995). Amongst the internal mechanisms of repression, being put into solitary confinement is usually the punishment most feared by inmates. Solitary confinement in Spanish prisons often involves being confined to a cell for around 21 hours per day with severe curtailment of communication with the outside world. However, women encountered frictions even in such hostile environment:

You just go ahead and do it, they can't deny me this. In my case I could leave the isolation cell for two hours or two hours and a half but I did my own stretching exercises in my cell. Who was going to stop me doing them in my cell? And what's more... you find a way of doing it, one way or another. And if you have no way, well I don't know but I can tell you! Some people run in their cells! [...] So when you are let out into the exercise yard for two hours, you come out as strong as a bull! Round, and round, and round the yard I would go, they can't deny me this. (Haizea)

Limitations to sport and physical activity and the constant tussle of rewards and punishments are not exclusive to solitary confinement. As pointed out by Martos-Garcia et al. (2009a, 2009b), prison-based activity largely rests upon a weak balance between therapeutic objectives and the demands of security, with the latter generally being the most important consideration. In this sense, sport and physical activity can also play a controlling role in modifying behaviours in prison. This is only allowed when behaviour conforms to the setting which in many cases is equivalent to submission. As Goffman 
suggested (1961), this amounts to a patent mutilation of the self. However, Goffman conceded that by way of small acts of resistance, labelled as secondary adjustments, power is challenged thereby strengthening the identity of the inmate. In consequence, the very practice of sport and physical activity is seen by our participants as a mechanism of personal afirmation, akin to a crack in the rigid disciplinary structure. Hence, participants were committed to it, even if this meant they had to create their own physical activity spaces in a context where these opporutnities were lacking:

I did aerobics in front of the TV. I used to grab two bottles of water and... (Haizea)

There are many possibilities, aren't there? Running, jumping over a stone, going up and down the stairs... grabbing a broomstick and hooking a bucket of water onto each end and you do it like this [she goes through the motion of using a bar-bell], there's always an option. (Beatriz)

Women's agency and their micro-resistances against the limitations associated to their imprisonment also affected human and material resources. Although therapeutic or recreational activities were conspicuous by their absence in the current study, the range of options typically available to women in Spanish prisons are aimed at reinforcing traditional female gender roles of wives and mothers, with a great emphasis on 'domesticity' (Almeda 2005). In this context, physical activities have a scant presence (Martinez-Merino et al. 2017, Meek and Lewis 2014). As Bosworth pointed out (1999), the women found their own way to get around the limitations of the prison setting. For example, participants made their own sporting equipment, their own world of sport, with anything they could use. Also, by helping each other with the activities they could compensate for the lack of fitness qualifications among them.

...there was a batuka aerobics instructor, her classes were great. Apart from giving us good advice and helping us, she believed it was the best way to kill time [...] She 
had learned to survive through physical exercise, in other words, doing sport. She offered batuka to us, it was really an immense help there. (Eguzki)

Prisons often lack qualified professionals or staff with an expertise on sports. This gap has not improved substantially, in view of the data presented in a recent study by Devís-Devís et al. (2017).

It is important to note that the prison setting necessarily imposes a certain degree of physical punishment. This is because the body of the prisoner is locked away, controlled and disciplined (Foucault 1995). Confinement in such a small space limits bodily mobility and leads to stiffness and seizures (Almeda 2005). Certain natural physical needs are created, such as the need to move; however, this situation is at loggerheads with the system and hence certain frictions take root (Rubin 2015). In this sense, Carolina affirmed that the need to move in prison is so essential that, should there be no possibility of moving, they would create a way to do so; her claim effectively ratifies her resistance to total submission:

I cannot imagine a place so confined over such a long time and with so many people not doing some kind of physical activity. I don't know but we would think of something, don't you think? We would not allow ourselves to wither away. As for me, if I saw a bench or something I would start exercising on it, right there and then. (Carolina)

The prisoners devise spaces where they regain control over themselves, as described by Rubin (2015), in this case resorting to sport and physical activity. Paradoxically, even in utter captivity the women enact gestures of micro-resistance in the form of small decisions, thereby affording themselves greater degrees of independence and freedom (Bosworth 1999, Ugelvik 2014).

According to Matthews (2009), the architecture of the prison implicates separating the inmates from the outside world, which results in a disconnection from the four 
elements of western culture (i.e. earth, air, fire and water). However, participants suggested that by participating in sport and physical activity they could (re)connect with these elements, which are thought to be essential to life. This is how Ekhine positioned herself regarding the penitentiary institution, thereby avoiding a sense of complete obliteration within herself:

I often reminded it to myself, when I went for a run in the yard in the wind and rain, and I thought: you've taken everything away from me, but you won't take this, nature still comes to me (Ekhine)

\section{The never-ending race against the clock}

The notion of separation from the outside world is not only physical, but it also manifests itself in the slow passing of time. For women prisoners, the time spent doing sport and physical activity seems to go quicker (see also Martos-Garcia et al. 2009a, 2009b). In prisons, time is at the core, with court sentences having a time limit. Based on the extension of capitalist production models, time has truly become a utilitarian commodity, something valuable and intrinsic to the very essence of incarceration (Matthews 2009). Consequently, if prison is understood as a space where women prisoners receive 'treatment' - to undergo correction and return as 'cured' women to society - it does not make sense to impose a penalty without a time limit (Foucault 1995). However, the perception of time inside and outside of prison is totally different (Matthews 2009). Following from this, prisoners battle with the passing of time by means of various evasion strategies, such as taking drugs. Along this line of thought, one of the women interviewed defined sport and physical activity as 'healthy drugs', due to the positive effect on the perception of time.

This is a vital issue if we consider that women express feelings of being in a time void, removed from their lives and from their loved ones. Physical activity becomes an 
effective evasion strategy within the prison routine, as has been indicated in other studies (Hulley et al. 2015, Schmid and Jones 1993, Ugelvik 2014). For the inmates, physical activity amounts to a micro-resistance that counteracts the sheer boredom of everyday prison life. As indicated by Rubin (2015), physical activity improves their experience of imprisonment. Marady talked about physical activity and the passing of time:

Of course. It makes the sentence lighter. It was an immense help to me. Because when I did sport the days seemed to pass more quickly. You know... a day in jail is long, it drags on. On the other hand, by doing sport, time just flies. (Marady)

Imprisonment changes the time that is lived in the physical, mental and social dimensions (Matthews 2009). In the case of mental time, the most subjective one, jail is supposedly a period of introspective reflection, an opportunity to correct oneself through solitude and remorse (Foucault 1995). But the truth is that the effects of loneliness and routine often lead to deep despair that may lead to depression and suicide. As we have discussed, taking part in sport and physical activity may help to regulate mental time in a positive way. With regards to social time, which connects the past, present and the future, and through which we can evaluate the changes experienced (Matthews 2009), prisoners find it difficult to make the pertinent connections. Not surprisingly, one of the principles of imprisonment is to isolate prisoners from the outside world (Foucault 1995), even though the rules that govern its operation express exactly the opposite: 'Life in prison shall approximate as closely as possible the positive aspects of life in the community' (Council of Europe 2006).

Following from this, participating in sport and physical activity can also serve as a connection to the future, in other words, to the exterior, as was the case with Ekhine. She used sport and physical activity to keep up contact with well-known popular marathons, ones that she symbolically 'ran' within the prison walls. The limits of the 
penitentiary discussed by Bosworth (1999) and De Graaf (2013), conditioned her practice in terms of time and space, but Ekhine created a strategy to belong to society despite finding herself behind bars:

Whenever there was a marathon on somewhere, I would say to myself: Right, I'm going to run it today and I was in fact creating my own marathon for as long as they let me, the longest time possible. (Ekhine)

Another participant, Simone, created parallel realities in her engagement with sport competitions. In this sense, Ugelvik (2014) expressed that a prisoner's imagination is a commonly used tool of resistance in that it provides respite from the sentence. While exercising, Simone gave free reign to her symbolic imagination:

Because I used to make a pelota match my own, for example, I would place a bet with myself, you're gonna get a third-grade regime, and bang-bang-bang, I would really go for it, right? That's how I set it up, I lived it. I would channel my wishes this way... just like in a game, right? Look, I would say, if I get that shot, or if I win a match, it's because I'm going to get some special permission, if I win I'll get, well, I don't know what. So, I gave the game all I had. I put everything into it as if all depended on me. Depended on that moment [...] I created those internal strategies, that imaginary space [...] I would do this for everything, right? Right from the moment we started a basketball or handball match, I would go deep into my fantasy and get high on it. And if I got eliminated ... the feeling of frustration was tremendous, the deception was so deep. Because I had put everything into it ... I couldn't have put more into it. But I kept on creating those parallel worlds. (Simone)

In the study by De Graaf (2013), women prisoners express that physical activity provides a space where they can focus on themselves, in an attempt to regain control over their bodies. As Simone explained, participating in physical activity can be an act of disobedience and resistance:

In general, playing sports helps, you feel free... You feel as if you only depend on yourself... You decide how much you want to do. It is a bit of... I would say it is a bit of resistance and allowed disobedience. (...) It is disobedience because you [referring to the 
corrections officer] haven't got control over my body, I control my own body. Then you are never going to see what my limit is, because it is me who decides what my limit is. And I am not going to share it with you. You think I am weak, but I am stronger than you think. (Simone)

\section{Hidding in the panoptic: eyes that (do not) see everything}

Power in prison is anonymous, distant and impersonal, but in practice, the exercise of power is carried out through the staff (Crewe 2007), who know the prisoners well. Prison staff, together with the CCTV cameras that can be found in prisons, are part of the system of control that Bentham (1995) identified as Panopticon. This concept was also theoretically developed by Foucault (1995), and the aim of such system is to constantly watch prisoners. By doing so, prison staff can evaluate prisoners' behaviours, which are then registered in their report. This report is then used to reward or punish prisoners depending on their behaviours. According to Nadia, it appears that sport and physical activity have positive impact on the evaluation of a prisoner's behaviour:

Nobody did any of the activities. I don't know why people are like that, if you want, even if it is only so that the prison wardens can see you, because a lot of the times what you get depends on the wardens. They're the ones who are with you all day, even though they are in their observation booths, chatting, whispering to each other, drinking coffee... In any case, they are looking at you! They know exactly what you're doing and what you are not. They know absolutely everything and they know why you're in jail, what you did, they know ... absolutely everything! So, if you want leave, do some activity, whatever you fancy, but do something! Even if it's just for yourself but nobody seems to want to do anything. They just want to sit down over there, in the yard if it's hot and in the common room if it's cold. Just sitting around watching the day go by. (Nadia)

According to the women interviewed, sport 'earned points' for the report. As affirmed by Crewe (2007), conformity to and compliance with the prison discourse must be visible 
and formal. It means that the inmates need to do what they are supposed to do. However, as the author pointed out, their actions are done in a masked way but with underlying resistance, all this with the exclusive objective of gaining rewards. Sonia explained this:

On the other hand you could go out every day, in the morning and in the afternoon, well, it was something that you looked forward to, I would say that today I'm going out [...] just to pretend a bit, but you ended up doing it because you met up with others from other cell blocks, friends... (Sonia)

The women prisoners learn to 'go along with the game' to improve their situation, suggesting that they are ready to become active agents in negotiating their lives (Bosworth 1999, Bosworth and Carrabine 2001, Ugelvik 2014). In this case, as described by Norman (2015), prisoners take advantage of sport and physical activity in the face of the social control they are subjected to. It is also important to note that socialization within the prison subculture is so intense and its disciplinary system so exhaustive (Foucault 1995), that women prisoners have interiorized the extrinsic value of participating in activities. This echoes Martos-Garcia et al. (2009b), and suggests the commodification of treatment in the 'great punitive market'. This market refers to how the punishments and rewards are negotiated within the prison. Notwithstanding this, apart from exemplifying a constant game that is played with the institution, some women have stated that participating in sport and physical activity has given them moments of collective pleasure.

Various studies have corroborated the value of exercise and sports in building up new social networks both outside the penitentiary setting (Fernandez-Lasa et al. 2015) and within (Gallant et al. 2015, Tibbetts 2015). In this way, women felt that they made a stand against the lack of solidarity that characterises the prison setting (Restrepo and Francés 2016), as well as creating an adaptation strategy for life behind bars (Hulley et al. 2015, Schmid and Jones 1993). 
Well really, at the end, you have a good laugh, you have an enjoyable time for a while, even though you are wary of being watched all the time, aren't you? They want to see you active, more or less active, don't they? (Natalia)

In any case, there is a very fine line that separates the intrinsic from the extrinsic in prison. Even in instances where utter control is clear (Foucault 1995), some inmates evade vigilance and take advantage of it. According to Nadia, she found an ideal market to meet people from other cell blocks in the sports hall. In doing so, she could sell her illicit 'goods' (i.e. drugs). This contraband activity has been considered a form of resistance (Crewe 2007, De Graaf 2013, Ugelvik 2014), and aims to make the prison experience more bearable. Although her intentions were not deliberately disruptive, Nadia defied patriarchal punitive power given that the sale and consumption of drugs is totally forbidden in prison:

I used to meet people and often, I'm not going to deny it, it was my opportunity to sell my stuff and that way I got some cash. [...] Look... you just fend for yourself. It's not so nice what you may have to do, you just have to make the best of it, to survive. (Nadia)

Previous authors have identified physical strength and muscularity as markers of masculinity, resilience and power within prisons (Jewkes 2005, Martos-Garcia et al. 2009a). For example, Norman (2015) observed that men often lifted weights in their cells. Although these practices may not be as common amongst women prisoners, Beatriz did perform exercises to improve her muscular strength and gain respect from other prisoners:

The fact is that some used sport, only a few really, you could count them with your fingers, to strengthen their bodies. And just to let you know, I'm a L'Oréal type, do you get me? "Wow, what a body!" you might say. "Well, that's why I spend three hours a day in the gym, right?" There were also those who were like that. Ones for whom sport was their one and exclusive passion ... but they used it a little for that 
too, you know... as if to say... Look here! Here I am and I'm strong, I do sport, so don't mess with me, right? So, respect me. (Beatriz)

These 'masks' are used to intimidate other prisoners as much as the prison wardens. Bosworth (1999) affirmed that for prisoners these masks provided personal protection, a shield against the stress and pressure exerted by the setting. It amounts to gaining the respect of others, in this case, by exhibiting a strong and tough-looking body. In short, these masks, are nothing more than yet another survival strategy commonly used by prisoners in their adaptation to incarceration (Hulley et al. 2015, Schmid and Jones 1993).

\section{Conclusions}

Even though control and power in prison are exhaustive, certain small cracks appear, figuratively speaking, through which prisoners attain some measure of evasion from their reality. According to the women interviewed, sport and physical activity may be a tool for micro-resistance when it comes to facing the power relationships surrounding imprisoned women, as well as providing a space that strengthens their identity and independence in captivity.

As observed in our study, sport and physical activity can become a symbolic survival instrument to cling to and they can provide an escape valve to relieve extremely desperate conditions. Furthermore, exercise helps the prisoners perceive that time passes more quickly and, making the sentence feel shorter. Sport and physical activity also have the potential to bring women closer to nature when exercising outside. By engaging in symbolic sport and physical activity practices, inmates can reconnect with the outside world and momentarily 'escape' from their prisoner status.

Participants used sport and physical activity to respond to social control. Being seen performing physical movement was not only pleasurable for participants, but it could 
award penitentiary benefits too. Participating in sport and physical activity was a form of body worship for some women, and building up muscles by 'sweating it out' was understood as a means of gaining social respect within a hostile environment.

Our research has elucidated the ways in which women negotiate and confront patriarchal punitive powers within prisons. In these systems, sport and physical activity can become manifestations of friction that lead to personal improvements in a hostile, often hopeless, environment. However, participating in sport and physical activity behind bars is not free from obstacles, prohibitions and limitations. In this context, the creation of micro-spaces of autonomy and freedom are worthwhile, valuable and precious.

\section{References}

Aebi, M. F., Tiago, M. M, Berger-Kolopp, L. and Burkhardt, C., 2017. Council of Europe, Annual Penal Statistics. SPACE I-Prison Populations. Survey 2016. Final Report. Council of Europe and University of Lausanne.

Almeda, E., 2005. Women's imprisonment in Spain. Punishment \& Society, 7 (2), $183-$ 199.

Ballesteros-Pena, A., 2017. Responsibilisation and female imprisonment in contemporary penal policy: 'Respect Modules'('Módulos de Respeto') in Spain. Punishment \& Society. Advance online pulication. doi :10.1177/1462474517710241.

Bentham, J. 1995. The Panopticon Writings. London: Verso.

Bosworth, M., 1999. Engendering resistance: Agency and power in women's prisons. Aldershot: Ashgate.

Bosworth, M. and Carrabine, E., 2001. Reassessing resistance race, gender and sexuality in prison. Punishment \& Society, 3 (4), 501-515.

Crewe, B., 2007. Power, adaptation and resistance in a late-modern men's prison. British Journal of Criminology, 47 (2), 256-275.

Davis, A.Y., 2016a. Democracia de la abolición: Prisiones, racismo y violencia [Abolition democracy: Prisons, racism and violence]. Madrid: Trotta.

Davis, A.Y., 2016b. Freedom is a constant struggle: Ferguson, Palestine, and the foundations of a movement. Chicago: Haymarket Books. 
De Graaf, K., 2013. Disciplining Women/Disciplining Bodies: Exploring how Women Negotiate Health and Bodily Aesthetic in the Carceral Context Thesis (PhD). University of Ottawa.

De Miguel-Calvo, E., 2016. Relaciones amorosas de las mujeres encarceladas [Imprisoned women's love relationships]. Bilbao: Servicio Editorial de la Universidad del País Vasco.

Devís-Devís, J., et al., 2017. Professionalization of Sport Educators in European Prisons. Revista Internacional de Medicina y Ciencias de la Actividad Física y el Deporte, 17 (66), 205-223.

Fernandez-Lasa, U., et al., 2015. Creating and maintaining social networks: women's participation in Basque pilota. RICYDE. Revista internacional de ciencias del deporte, 40 (11), 129-144.

Foucault, M., 1982. The subject and power. Critical inquiry, 8 (4), 777-795.

Foucault, M., 1990. Power and Sex: Discussion with Bernard-Henri Levy. In: L.D. Kritzman, ed. Michel Foucault: Politics, Philosophy, Culture: Interviews and Other Writings: 1977-1984. USA: Routledge, 110-124.

Foucault, M., 1995. Discipline and Punish: The birth of Prison. NY: Vintage Books.

Foucault, M., 1996. La vida de los hombres infames [The life of the infamous men]. La Plata: Caronte Ensayos.

Gallant, D., Sherry, E., and Nicholson, M., 2015. Recreation or rehabilitation? Managing sport for development programs with prison populations. Sport Management Review, 18 (1), 45-56.

Gannon, S. and Davies, B., 2007. Postmodern, poststructural, and critical theories. In: S.N. Hesse-Biber, ed. Handbook of feminist research: Theory and praxis. Thousand Oaks: Sage, 71-106.

Goffman, E., 1961. Asylums: Essays on the social situation of mental patients and other inmates. New York: Anchor Doubleday.

Hargreaves, J. and Anderson, E., 2014. Routledge handbook of sport, gender and sexuality. London: Routledge.

Hulley, S., Crewe, B., and Wright, S., 2015. Re-examining the problems of long-term imprisonment. British Journal of Criminology, 56 ( 4), 769-792.

Jewkes, Y., 2005. Men behind bars. "Doing" masculinity as an adaptation to imprisonment. Men and Masculinities, 8 (1), 44-63.

Kvale, S., 2007. Doing interviews. London: Sage publications.

Lewis, G. and Meek, R., 2012. Sport and physical education across the secure estate: an exploration of policy and practice. Criminal Justice Matters, 90 (1), 32-34 
Martinez-Merino, N., et al., 2017. Physical activity practiced by incarcerated women: A systematic review. Health Care for Women International, 38 (11), 1152-1169.

Martos-Garcia, D., Devís-Devís, J., and Sparkes, A.C., 2009a. Sport and physical activity in a high security Spanish prison: an ethnographic study of multiple meanings. Sport, Education and Society, 14 ( 1), 77-96.

Martos-Garcia, D., Devís-Devís, J. and Sparkes, A.C., 2009b. Deporte entre rejas ¿Algo más que control social? [Sport 'behind bars' Anything beyond social control?] Revista Internacional de Sociología, 67 (2), 391-412.

Martos-Garcia, D. and Devís-Devís, J., 2017. "Ver, oír, callar y... aburrirse" en el trabajo de campo: el relato autoetnográfico de un estudio en la prisión ["See, hear, remain silent and...bored" in the fieldwork of a prison: an autoethnografic story]. Movimento, 23 (1), 53-66.

Matthews, R., 2009. Doing time: An introduction to the sociology of imprisonment. 2nd ed. UK: Palgrave Macmillan.

Meek, R. and Lewis, G.E., 2014. Promoting well-being and desistance through sport and physical activity: the opportunities and barriers experienced by women in English prisons. Women \& Criminal Justice, 24 (2), 151-172.

Norman, M., 2015. Sport in the underlife of a total institution: Social control and resistance in Canadian prisons. International Review for the Sociology of Sport, $52(5), 598-614$

Norman, M., 2018. Researching sport in a 'Total Institution': reflections on research barriers and methodological adaptations in a study of prison physical culture. Qualitative Research in Sport, Exercise and Health, 10 (1), 17-31.

Noy, C., 2008. Sampling Knowledge: The Hermeneutics of Snowball Sampling in Qualitative Research. International Journal of Social Research Methodology, 11 (4), 327-344.

Council of Europe. Committee of Ministers. 2006. European Prison Rules. Council of Europe.

Restrepo, D. and Francés, P., 2016. Rasgos comunes entre el poder punitivo y el poder patriarcal [Common Traits of Punitive and Patriarchal Power]. Revista Colombiana de Sociología, 39 (1), 21-46.

Rubin, A.T., 2015. Resistance or friction: Understanding the significance of prisoners' secondary adjustments. Theoretical Criminology, 19 (1), 23-42.

Schlosser, J.A., 2008. Issues in Interviewing Inmates. Navigating the Methodological Landmines of Prison Research. Qualitative Inquiry, 14 (8), 1500-1525.

Schmid, T.J. and Jones, R.S., 1993. AMBIVALENT ACTIONS Prison Adaptation Strategies of First-Time, Short-Term Inmates. Journal of Contemporary Ethnography, 21 (4), 439-463. 
Taylor, S.J., Bogdan, R. and DeVault, M.L., 2016. Introduction to Qualitative Research Methods a Guidebook and Resource. 4th ed. USA: Wiley.

Tibbetts, E.S., 2015. Understanding incarcerated women's motivation to exercise (PhD). Temple University.

Ugelvik, T., 2014. Power and resistance in prison: doing time, doing freedom. Basingstoke: Palgrave Macmillan.

Wacquant, L., 2009. Prisons of Poverty (expanded edition). Minneapolis: University of Minnesota Press. 